\title{
Dental and oral management in beta major thalassemia in children
}

\author{
Eriska Riyanti
}

\author{
Department of Pediatric Dentistry Faculty of Dentistry Universitas Padjadjaran
}

\begin{abstract}
Thalassemia beta major is a hereditary hemolytic anemia disease with various grades of severity, which can be found with no or less globin chain qualitative synthesis. The patient often experiences hepatosplenomegaly, growth retardation and bone disorder and the thalassemia facies/chipmunk face appearance. The orofacial manifestations of beta thalassemia major are prominent cheek bones and protrusive premaxillae due to erythroid hyperplasia with depressed bridge of the nose. The dentition shows protrusion, flaring and spacing of the maxillary anterior teeth, open bite that leads to malocclusion. The anemic condition makes the patient is difficult to do all oral hygiene instruction thus caries index will increase. Dental practitioners especially pediatric dentists are required to have awareness towards the nature of the disease and its implication on dental care. Collaboration with hematologist has to be made in every dental treatment.
\end{abstract}

Key words: Thalassemia beta major, orofacial disorders, thalassemia facies

\section{INTRODUCTION}

Recently, thalassemia has been found in several countries. The main distribution of this disease includes boundary areas of the Mediteranian Sea, most of Central Africa, Middle East, India sub-continent and South East Asia including Indonesia with an incidence of 5-20\%.1,3 Currently, in Indonesia it is estimated that there are around 5,000 beta major thalassemia patients with around 380 patients are treated in Dr. Hasan Sadikin General Hospital Bandung. Six to ten of 100 Indonesian carry the gene for this disease. The Ministry of Health estimates that one of 1,600 newborn in Indonesia suffers from severe thalassemia and 200,000 of all newborn suffers from minor thalassemia. The Thalassemia Center in Cipto Mangunkusumo General Hospital Jakarta serves 1,200 patients every month, while the thalassemia clinic at Dr. Hasan Sadikin General Hospital serves about 380 patients. The data shows that thalassemia disease prevalence in Indonesia is quiet high.

Talking about thalassemia, it is difined as a hereditary hemolytic anemia with various degrees of severity characterized by no or less globin chain synthesis due to the abnormal genetic globin chain quantitative synthesis that is commonly found in the whole world. This disease may be caused by marriage between two thalassemia carriers and is often found among children because the patients of this type of thalassemia rarely reach adulthood. In Ferrara, the thalassemia patients who reach the age of six years are only $9 \%$ in the period of 
1949 to 1957 . In the half 1970 's, half the of the patients in Italy died before the age of 12 . About $3 \%$ of the world population, i.e. 150 millions, have beta mayor thalassemia gene. The genetic factors appears to trigger thalassemia, which is in line with the findings reported by the researchers from Lembaga Biologi Molekuler Eijkman (Eijkman Biology Molecular Center) in Sumatera and East Nusa Tenggara that shows a small percentage in South Sumatera may reach 15 percent; in Sumba East Nusa Tenggara, it reaches $36 \%$.

Meanwhile, stated that thalassemia is a typical genetic disease of the tropical population such as Sardinia, Italy, Cyprus, Mediteranian, and all Asian country to Papua New Guinea. This difference shows an evident the relationship between the genetic factors and thalassemia. ${ }^{4}$

In general, this disease shows severe chronic anemia that is characterized by paleness, weakness, fatigue and malaise. The most severe symptoms are found in beta mayor thalassemia. This type of thalassemia is also known as Cooley anemia, which is the most severe congenital hemolytic anemia. The chronic hemolytic anemia symptoms in patients progressively appear since the age of 3-6 months leading to the need of routine blood transfusion. This condition makes the patients lazy to clean their teeth leading to poor oral hygiene and high caries index. While the typical thalassemia patients have a particullarly face called as facies rodent because of the protrusive anterior teeth and disturbed maxilla growth that may cause malocclussion. In this case, it is no doubt that that thalassemia may give alteration of oral cavites condition.

\section{BETA MAYOR THALASSEMIA}

Beta thalassemia is caused by chromosome 11 mutations that may affect all beta chain production such as transcription, translation and beta globin chain production stability. ${ }^{10-12}$ Beta thalassemia is classified into two categories; beta plus, where the beta chain production is reduced; and beta zero, where there is no beta chain production found. ${ }^{2,7}$ This beta zero thalassemia is known as beta mayor thalassemia and beta plus thalassemia is known as intermediate beta thalassemia. ${ }^{4,7,9}$ Beta mayor thalassemia is a homozygote beta thalassemia disorder that is often called Cooley anemia. Its clinical manifestation usually appears after 4-6 months of life $\mathrm{e}^{7,9,13}$ and the patients experience severe anemia with less than $20 \%$ hematocryte that leads to dependency towards blood transfusion. ${ }^{7,9,11}$ It shows that this kind of thalassemia is the most severe form of thalassemia.

In fact, this disease is a recessive autosomal familial disease and particularly attacks beta globin gene. ${ }^{12-14}$ When both parents are carrier of the disease, there is a possibility that one of their four children has thalassemia, two are carriers and one of them is normal ${ }^{14}$ and is often caused by the inheritance of two different mutation, each recognizes beta globin synthesis (mixed heterozygote). Therefore, the pathogenesis of beta thalassemia includes genetic mutation leading to beta polypeptide chain connection deviation in globin that affects beta chain synthesis. ${ }^{7-13}$ Globin chain disorder may happen in the alpha or beta chains and may appear in the homozygote individuals and heterozygote individuals. ${ }^{6-10}$ As a result, globin beta chain synthesis is reduced.

As mentioned above, beta chain production will be disturbed leading to drastically decreased hemoglobin level. This is caused by excessive destruction of ineffective red blood cells in the spleen that a routine blood transfusion is a must. ${ }^{15}$ There is a severe hypochrome microcystic, anisopoikilocytosis with a high reticulocyte percentage along with normoblast, target call and basophilic stippling on the peripheral blood smear preparation of the beta mayor thalassemia patients. ${ }^{12-5}$ This condition provides a certainty that the diagnosis must be made through hemoglobin electrophoresis by showing the absence of $\mathrm{HbA}$, normal, low or a bit higher percentage of $\mathrm{HbA2}$ and almost all hemoglobin in the blood are HbF. A positive Kleihauer test result that determines $\mathrm{HbF}$ using acid elution method is used to support diagnosis. ${ }^{12-6}$

Talking about decreased hemoglobin due to beta chain deficiency, there is compensation from decreased $\mathrm{HbA}$ level and increased production of $\mathrm{HbA2}$ and $\mathrm{HbF}$ will lead to various clinical signs. ${ }^{5,9,14}$ The most common symptoms are spleen and liver enlargement, delayed bone growth and changes in bones. ${ }^{7}$ The changes in bones are due to the bone marrow hyperactivity that causes excessive growth in frontal bone, zygomatic, and 
maxillary protrusion. This changed form leads to a typical facial appearance called thalassemia facies. The dental growth of the beta mayor thalassemia patients is poor and is accompanied by jaw bone refraction. ${ }^{14}$ Beside, beta mayor thalassemia patients have a short life expectancy. The most severe patients rarely reach adulthood. In addition, the repeated big amount of blood transfusion accompanied by abnormal increased of iron will create a new complication. ${ }^{15-16}$

Meanwhile, there are two factors related to anemia pathogenesis in beta thalassemia are reduced beta globin synthesis and beta thalassemia hemolytic components. Beta globin synthesis reduction continues into abnormal erythroblast formation so that the total hemoglobin level for each cell is lower and the cell looks hypochromic. ${ }^{13,15}$ The beta thalassemia hemolysis component is not caused by beta globin deficiency but due to the excessive globin alpha chain with normal synthesis. The alpha free chain forms insoluble pool and creates sediment in the erythrocyte. This input damages the cell layer, reduce the flexibility and decrease the red cells. ${ }^{16}$

\section{The clinical manifestation of beta mayor thalassemia}

The clinical symptoms of beta mayor thalassemia are seen when $\mathrm{HbF}$ is normally replaced by $\mathrm{HbA}$, i.e. in the age of 3-6 months after birth and is characterized by severe anemia due to the absence of HbA synthesis. ${ }^{17-18}$ Babies with beta mayor thalassemia will look pale with extended abdominal area due to the splenomegaly and failures in growth and development. ${ }^{13-19}$ The child's weight is usually lower than the average weight for his/her age. Fever, diarrhea and various gastrointestinal disorders are usually found during the first year of life. ${ }^{14}$ The skin looks pale and yellowish and will become dark due to the iron sedimentation caused by repeated transfusion. ${ }^{7}$

While the bone abnormalities happen mostly due to the erythroid marrow hypertrophy and expansion that leads to widen bone marrow, thin cortex and osteoporosis. ${ }^{15,19}$ The bone abnormalities are found initially in the metatarsal and metacarpal bones in the shape of rectangular convex site caused by increased erithropoiesis leading to bone marrow widening. ${ }^{19-23}$ Older patients commonly show a typical face called facies Colley with abnormal facial and cranial bone growth. The nose looks flat without nasal bridge, the distance between eyes is wide and the forehead bone is wide too. There is a thickening of cheek bones and deep nose bridge that leads to the typical features of facies Cooley. The teeth look protrusive and the disturbed maxillary growth will create malocclusion. ${ }^{19-24}$

Moreover, medullar tubercle gives a mosaic feature of the bone. Osteoporosis and cortical thinning may lead to pathological fracture in long bones and shortened arms due to irregular fusion of the humerus proximal area. ${ }^{36,39,42}$ The ribs are widened especially in the area where the vertebras meet that leads to increased Para vertebrae mass and pressure to the cord (cord compression). ${ }^{19-20}$ The characteristic and the severity of the bone abnormalities increase with age. In older patients, the bony changes are more commonly found in the distal areas such as legs and arms. ${ }^{31,46,48}$

Other thanclinical symptoms havementioned above, there is a heart abnormality that is often found and is included into one of the death causes. Myocardial hemocyderosis or heart disorder caused by hemochromatosis is one of the death causes in patients who receive routine transfusion. $2,7,9$ Hemocyderosis evokes arrhythmia that also causes sudden death. The abnormality that is caused by severe anemia is hearth enlargement that can be accompanied by congestive heart failure. ${ }^{11,13,17}$ Pericarditis may happen due to the severe iron sedimentation in the pericardium as well as the bacterial infection. ${ }^{20}$

Beta mayor thalassemia patient growth and development are commonly disturbed even though the relative intelligence level development is not affected. This obstructed growth is caused by the severe anemia and low $\mathrm{Hb}$ level leading to tissue hypoxia. The secondary sexual growth is disturbed by the endocrine disorders that puberty is reached later and the growth acceleration is delayed or even does not occur. Menstruation in girls and secondary sexual signs in boys are delayed. ${ }^{17}$

While in the older patients, Diabetes mellitus and hypoparatiroidism is commonly found due to the endocrine disorder. ${ }^{12,16,17}$ The beta mayor thalassemia patients are also medically compromised patients because they are susceptible to infections. 


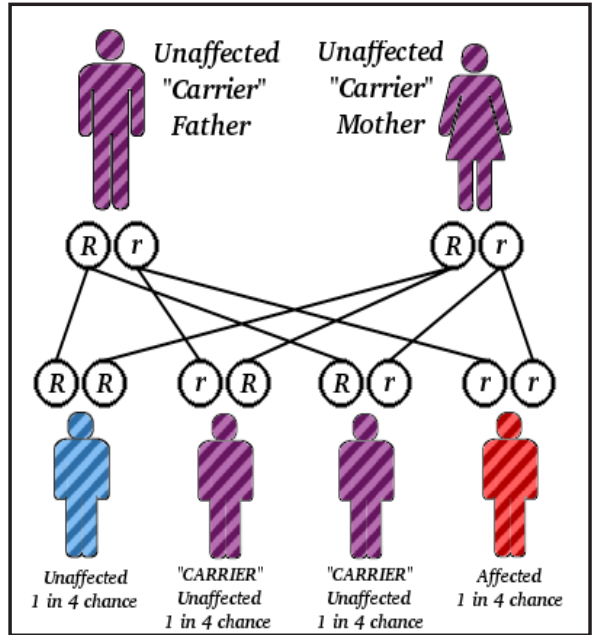

Figure 1. Beta mayor thalassemia genetic pattern. ${ }^{7}$

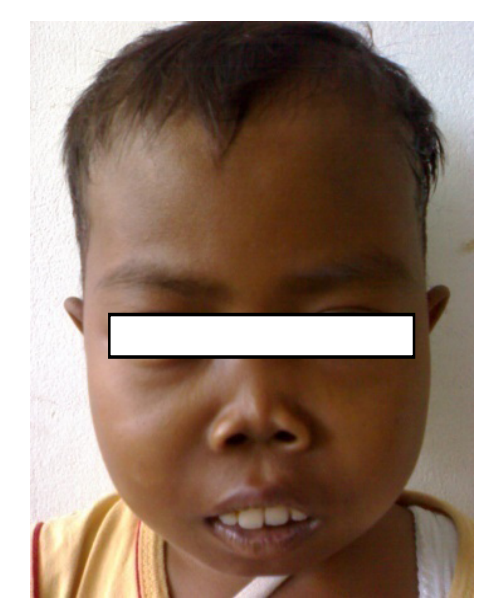

Figure 2. Facies Cooley.

The kidney is usually enlarged as a result from extra medullar hematopoiesis with dark brown urine cased by heme catabolism product excretion. ${ }^{17-20}$

\section{DISCUSSION}

Growth and development of oral cavity in beta mayor thalassemia patients show several differences compared to normal children especially in terms of facial bone structures, dental arrangement and gingival color.

\section{Beta mayor thalassemia craniofacial growth and development characteristics}

The face and head of beta mayor thalassemia patients show a typical form known as facies Cooley or fasies thalassemia. The cranial bone is thickened resulting in frontal bone protrusion with widened diploe space and thin external and internal plate. The excessive malar bone grow due to the erythroid marrow expansion creates prominent cheeks and deep nasal base. According to Meredith and Higley, there is a relationship between the transversal grow of the head and face with the dental arch. The excessive maxillary bone grow creates dental malocclusion. The pneumatization of the maxillary sinus is commonly delayed in beta mayor thalassemia patients. , $^{9} 20-3$

\section{Radiographic characteristics of beta mayor thalassemia}

The changes in beta mayor thalassemia patient bones that are caused by bone marrow hyperplasia can be observed in the radiographic images. Diploe in the cranial bones experience expansion that the inter plate space becomes widened while the external and internal part of the plate becomes thinner. The frontal bone creates a vertical tubercle that is parallel with the diploe plate external plate and, due to erythroid hyperplasia, the parietal bone has a porous part in the diploe plate external part that creates hair on end or sun ray appearance. ${ }^{3,20-8}$ The tubercle on the jaw bone can be seen in the panoramic image and gives a Honeycomb appearance. ${ }^{19-24}$

\section{Oral cavity characteristics of beta mayor thalassemia patients}

The oral cavity of the beta mayor thalassemia patients shows the following characteristics. ${ }^{20-4}$ The upper jaw seems to be bigger due to the bone marrow expansion. This facial feature is known as chipmunk facies. The lower jaw is wider than a normal lower jaw. The tooth size is similar to normal child tooth except for the multiple diastema due to faster jaw growth. The periodontal ligament will seem widened as a result from Class II Division 1 malocclusion. The gingiva is pale especially when the patient's $\mathrm{Hb}$ drops to below $8 \mathrm{gr} / \mathrm{dl}$. The color of the gingiva sometimes tends to be dark, which is caused by the high ferritin level in the blood. The tongue size is bigger/macroglossi as a result from bigger arches.

\section{Considerations during dental treatment}

The treatment for beta mayor thalassemia is performed routinely especially when patients experience decreasing hemoglobin level. Therefore, the dental treatment should be 


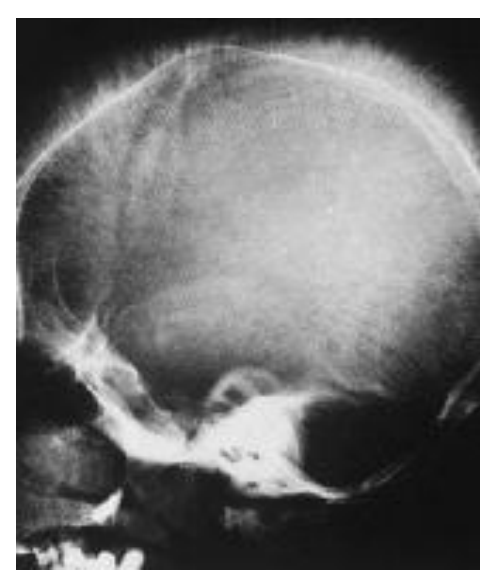

(A)

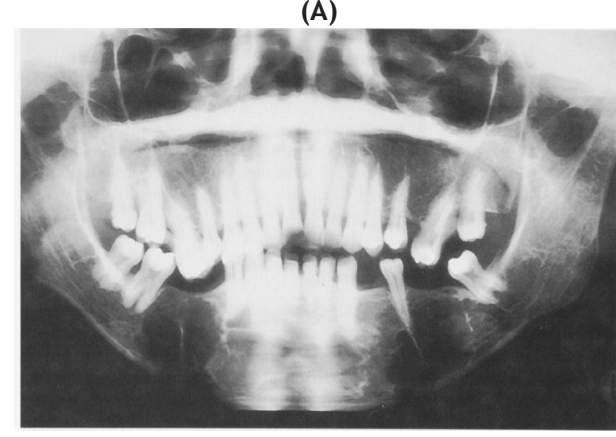

(B)

Figure 3. (A) Hair on end appearance in the cranium and (B) Honeycomb appearance in the panoramic image. ${ }^{19,24}$

performed by paying attention to these following considerations: ${ }^{24,29}$ Consult all dental treatments planned with the hematologist. The dental treatment should be performed in a short time as possible and should be done after the patient receives blood transfusion. Do not do dental treatment when the hemoglobin level is less than $100 \mathrm{~g} / \mathrm{l}$. Provide antibiotics prophylaxis especially for children who have undergone splenectomy. If an orthodontic treatment is needed, the dental movement should be watched closely because there may be faster movement compared to the normal situation. The retention phase is also more difficult in these patients.

\section{CONCLUSION}

The anemic condition in beta major thalassemia patients makes patients lazy to clean their teeth that the oral hygiene becomes poor and a high caries index is found. The dentist, especially the pediatric dentist, should be careful in giving dental treatment. The cooperation with the hematology expert should be established in each treatment action.

\section{REFERENCES}

1. Leavell BS, Thorup OA. Fundamentals of clinical hematology. Philadelphia: W.B. Saunders Co; 1960.

2. Robbins SL, Kumar V. Buku ajar patologi II. Jakarta: EGC; 1995.

3. Nelson WE, Behrman RE, Kliegman RM, et al. Nelson: Ilmu kesehatan anak. $15^{\text {th }}$ ed. Jakarta: EGC; 1999.

4. Sjahruddin LD. Indeks kelainan dentofasial dan maturasi tulang vertebra servikal pada penderita thalassemia beta hemoglobin E serta hubungannya dengan beberapa faktor risiko. Dissertation. Jakarta: Universitas Indonesia 2004;3:47-48:51

5. Gandy A. Thalassemia-beta. Available from: http:/ / www.icondata.com/health/pedbase/ file/THALASSE.HTM.1994.

6. Behrman RE, et al. Williams hematology. $5^{\text {th }}$ ed. New York: Mc Grow Hill, Inc.; 1995.

7. Greer JP, Foerster J, Lukens JN, et al. Wintrobe's clinical hematology. $11^{\text {th }}$ ed. Philadelphia: Lippincott Williams \& Wilkins; 2004. p. 5,8,10,12,17,18,22-48.

8. Beutler E, Lichtman MA, Coller BS, et al. William's hematology. $5^{\text {th }}$ ed. USA: MC Graw Hill; 1995. p. 12,14,15-17.

9. Miller DR, Baehner RL, Miller LP. Blood diseases of infancy and childhood. $7^{\text {th }}$ ed. St. Louis: Mosby; Year Book. Inc.; 1995. p. 8,9,18-19.

10. Lee GR, Foerster J, Lukens JN, et al. Wintrobe's clinical hematology. $10^{\text {th }}$ ed. Philadelphia: Lippincott Williams \& Wilkins; 1999. p. $1,5,9,14,15,17,19-48$.

11. Nathan DG, Oski FA. Hematology of infancy and childhood. $4^{\text {th }}$ ed. Philadelphia: WB Saunders Co; 1993. p. 22

12. Benz EJ, Giardina PJV. Thalassemia syndromes. In: Miller DR, et al. Blood of infancy and childhood. $7^{\text {th }}$ ed. USA: Mosby. 1995.

13. Thein SL. Genetic insights into the clinical diversity of beta thalassaemia. $\mathrm{Br} \mathrm{J}$ Haematol 2004;124:264-74.

14. Pathophysiology of beta thalassemia: A guide to molecular therapies. USA: The American Society of Hematology: 2005.

15. Behrman RE, et al. Nelson textbook of Pediatrics. $17^{\text {th }}$ ed. China: W.B. Saunders Co; 2004. 
16. Weatherall DJ. The thalassemia syndromes. $3^{\text {rd }}$ ed. Oxford: Blackwell Scientific Publications Ltd.; 1981.

17. Fortnightly review: The thalassaemias. BMJ 1997;314:1675.

18. Kumar S. Beta globin gene and delated diseases: A Review. Int J Hum Genet 2002;2(3):139-52.

19. Cohen A, Schwartz E. Practice of pediatrics. Vol. 5. Philadelphia: Harper and Row; 1986.

20. Lynch MA. Burkett's oral medicine diagnosis and treatment. 9th ed. Philadelphia: J.B. Lippincott Co.; 1994.

21. Al-Wahadni A, Qudeimat MA, Al-Omari M. Dental arch morphological and dimensional characteristics in Jordanian children and young adults with beta thalassemia major: Intl $\mathrm{J}$ of Pediatric Dent 2005;15:98-104.

22. Alhaija ESJA, Hattab FN, Al-Omari MAO. Cephalometric measurement and facial deformities in subjects with beta-thalassaemia major. Eur J Orthod 2002;24: 9-10.

23. Hazza'a AM, Al-Jamal G. Radiographic feature of the jaws and teeth in thalassaemia major. Dentomaxillofac Radiol 2006;35:283-8.

24. Greenberg MS, Glick M. Burket's oral medicine. $10^{\text {th }}$ ed. Spain: B.C. Decker Inc.; 2003.

25. Wonke B. Bone disease in beta thalassaemia Major. Br J Haematol 1998;103:897-901.

26. Cao A. Thalassemia: As a model. [cited 2007 March 14] Available from: http://www. charite.de/ch/medgen/eumedis/medgen05/ thalassemia-amodel.html.2005.

27. Elstrom R. Clinical thalassemia (major and minor). [cited 2007 April 25] Available from: http: / /www.nhlbi.nih.gov/Ency/article/ 000587.htm.2001.

28. Cannel $\mathrm{H}$. The development of oral and facial signs in beta thalassemia major. $\mathrm{Br}$ Dent $\mathrm{J}$ 1988;164:50-1.

29. Cameron AC, Widmer RP. Handbook of pediatric dentistry. Philadelphia: Mosby; 2003. 